\title{
5.3. РАЗВИТИЕ ФИНАНСОВ ОБЩЕСТВЕННОГО СЕКТОРА В УСЛОВИЯХ ЦИФРОВОЙ ЭКОНОМИКИ
}

Захарова Н.М., старший преподаватель, Департамент общественных фринансов

Финансовый университет

при Правительстве РФ, г. Москва

Предмет исследования - развитие цифровых платформ управления общественными финансами: государственной интегрированной информационной системы «Электронный бюджет» и Единой информационной системы в сфере закупок. Итогом исследования стало заключение о том, что цифровые технологические решения теперь являются незаменимыми инструментами управления общественными финансами в условиях быстро меняющейся экономической среды под воздействием глобальных и локальных вызовов. Цель работы - установление основных механизмов цифровизации сектора общественных финансов для обеспечения прозрачности и открытости деятельности органов власти, государственных и муниципальных учреждений, повышения их результативности и эффективности работы в рамках единого информационного пространства. Технологии способствуют преобразованию общественного сектора и изменяют принципы оказания государственных (муниципальных) услуг. Формализация процессов и процедур обеспечивает более прозрачное и регламентированное взаимодействие с государственными органами власти. Эффективное использование новейших информационно-телекоммуникационных технологий позволит перейти на новый уровень управления общественными финансами.

\section{Литература}

1. О внесении изменений в приказ Министерства финансов РФ от 28 декабря 2016 г. № 243н «О составе и порядке размещения и предоставления информации на едином портале бюджетной системы РФ» [Электронный ресурс] : приказ М-ва финансов РФ от 28 дек. 2018 г. №296н. Доступ из справ.-правовой системы «Консультант Плюс».

2. Абдрахманова Г.И. и др. Цифровая экономика [Текст] : крат. стат. сб. / Г.И. Абдрахманова, Л.М. Гохберг, АВ. Демьяненко и др. - М. : НИУ ВШЭ, 2018.

3. Аптекман А. и др. Цифровая Россия: новая реальность [Электронный ресурс] / А. Аптекман, В. Калабин, В. Клинцов и др. M. : Digital/McKinsey, 2017. - URL: https://

4. www.mckinsey.com/ /media/mckinsey/locations $\neg /$ europe

5. Единая информационная система в сфере закупок [Электронный ресурс]. - Режим доступа: http://zakupki.gov.ru/epz/main/public/home.html

6. Казначейство Российской Федерации [Электронный ресурс] : официальный сайт. - Режим доступа: https://roskazna.ru/

7. I-DESI 2018: How digital is Europe compared to other major world economies? [Electronic resource]. - URL: https://ec.europa.eu/digital-single-market.

\section{Ключевые слова}

Цифровая экономика; информационные ресурсы; управление общественными финансами; цифровая платформа; единое информационное пространство; электронный бюджет; единый портал бюджетной системы; автоматизация бюджетного процесса.

\section{Захарова Наталья Михайловна}

\section{РЕЦЕНЗИЯ}

Актуальность проблемы: Актуальность исследования обусловлена тем, что использование цифровых технологий позволяет повысить результативность и эффективность управления финансами общественного сектора, сократить время на принятие финансовых решений, увеличить количество объектов контроля, работающих без нарушения законодательства. Цифровые технологии в организации фринансов общественного сектора значительно расширяют возможности как автоматизации процессов, ранее требовавших ручного труда, так и использования новых способов обработки и представления информации. Изменение приемов работы в управлении финансами общественного сектора в условиях цифровой экономики означает возникновение спроса в сфере государственного управления на навыки и умения иного рода, а также на обеспечение большей надежности в распоряжении государственными средствами.

Научная новизна и практическая значимость: В представленной работе автором доказано, что развитие технологий позитивно влияет на эфрфективность бюджетного процесса, увеличение количества доступной информации и повышение ее качества. Использование информационных технологий является основополагающей составляющей открытости и прозрачности государственного управления, что является крайне важным для повышения эффективности управления общественными финансами. Практическую значимость имеет авторское исследование роли цифровых технологий и действующих цифровых платформ в решении стоящих перед органами государственного управления вопросов, авторское обоснование преимуществ и недостатков специально разработанных для государственных нужд цифровых платформ управления общественными финансами (ГИИС «Электронный бюджет», Единый портал бюджетной системы РФ, Единая информационная система (ЕИС) в сфере закупок) по сравнению с использованием стандартных систем формирования, обработки и хранение информации для управления финансами общественного сектора.

Заключение: рецензируемая статья отвечает требованиям, предъявляемым к научным публикациям и может быть рекомендована к опубликованию.

Шмиголь Н.С., к.э.н., доцент, доцент Департамента общественных финансов, Финансовый университет при Правительстве РФ, г. Москва.

DOI 10.38097/AFA.2020.10.21.012 